\title{
Improvement of Teachers' Performance through Development of Emotional Intelligence, Organizational Culture and Principal's Supervision
}

\author{
Mualimah*, Soewarto Hardhienata, Entang \\ Postgraduate Program, Pakuan University Bogor, Indonesia
}

*Corresponding Author: Mualimah, Postgraduate Program, Pakuan University Bogor, Indonesia

\begin{abstract}
Performance of elementary school teachers is essential to improve the quality of graduates carried out through the learning process in school. This study aims at exploring the relationship between emotional intelligence, organizational culture and supervision of principals with teacher performance both individually and simultaneously. This research was conducted on public elementary school teachers in Jambi, Indonesia. The study sample was 282 teacher respondents taken from 948 elementary school teacher populations. This study uses correlation techniques to assess the strength of the relationship between the variables studied. Scientific Identification Theory of Operation Research in Education Management (SITOREM) is employed to determine the hierarchy of necessity.

The main conclusion of this study is that there is a significant positive relationship between emotional intelligence and teacher performance $\left(r_{y l}=0.618\right)$, between organizational culture and teacher performance $\left(r_{y 2}=0.609\right)$, between supervision of principals with teacher performance $\left(r_{y 3}=0701\right)$, between emotional intelligence, organizational culture and supervision of school principals with teacher performance $\left(r_{y 123}=\right.$ 0.731). Data collection in the qualitative stage through observation, interviews, document studies, and focus group discussions showed results that supported the conclusion of the quantitative research phase. SITOREM reveals that teacher's knowledge development should be prioritized.

Keywords: Teacher Performance, Emotional Intelligence, Organizational Culture, Principal Supervision
\end{abstract}

\section{INTRODUCTION}

Teacher performance in schools is crucial for improving the quality of education. This is reasonable because the individual performance of a teacher will reflect the degree of school competition. School progress and retreat are greatly influenced by teacher performance. Likewise, the quality of education is inseparable from the role of teacher performance in improving the quality of education. When observed, the factors that influence the performance of the teacher mentioned above, it can be said that in general the factors that influence the performance of teachers both in school are almost the same. Where this can be seen according to performance as a process of one's ability to complete work from "raw input" until it reaches "output." These factors include emotional intelligence, organizational culture, and supervision (Mohtar \& Rajiani, 2016).

Good performance can contribute to organizations or institutions so that the goals that have been announced can be achieved. According to Colquitt, et al. (2009: 37) performance is formally defined as the value of all employee behaviors that contribute (reciprocal contribution) positive or negative for achieving organizational goals. Definition of work behavior includes behaviors that control employees. So employees contribute good behavior, positive and negative behaviors that are appropriate or not by the achievement of work results. This definition implies that performance includes both positive and negative values performed by employees. This behavior is the control within employees that will be related to their performance. The work results obtained by someone in carrying out their duties are the output of the work process.

The performance measures according to Mitchell and Larson quoted by Sedarmayanti (2009) are seen from five things, namely 1) Quality of work, 2) Promptness (timeliness of completing work), 3) Initiative (initiative in completing work), 4) Capability (having the capacity to complete work), 5). Communication (cooperation with other parties). 
Petridis and Fordham (2010) propose to make two different concepts of emotional intelligence based on differences in measurement methods. The first concept, emotional intelligence as the ability (emotional intelligence ability) refers to the ability to feel, undergo, and utilize information that is effective. The second concept, emotional intelligence is a character (trait emotional intelligence or emotional self-efficacy) which refers to a series of perceptions and personal tendencies about emotional aspects.

Related to the nature of emotional intelligence, Zeidner et al. (2009), states; the nature of emotional intelligence represents the overall personality. Like typical personality traits, the nature of EI is a qualitative style of behavior and adaptive experience in several contexts but not others. The challenge then integrates the nature of emotional intelligence and aspects in standard personality research. Whether working on the nature of emotional intelligence adds a new aspect to the existing personality model or explains the traits that exist from different perspectives. As a trait, EI is considered an innate characteristic that enables and promotes well-being.

Luthans (2011) defines organizational culture as an underlying pattern of assumptions that are created, discovered, or developed by a particular group of learning outcomes to overcome problems through external adaptation and internal integration, which works quite well for valuable considerations and, therefore, to be taught to new members as a correct way of understanding, thinking, and feeling related to the problem.

Furthermore according to Colquit (2009), organizational culture: "is a shared social knowledge within an organization regarding the rules, norms, and values that shape the attitudes and behaviors of its employees." This definition implies that organizational culture as part of social knowledge in an organization includes there are rules, norms, and value values that shape the attitudes and behavior of people within the organization. Furthermore, DuBrin (2012) states, "organizational culture (or corporate culture) is the system of shared values and beliefs that actively influence the behavior of organization members." So the definition means that organizational culture is a system of organizations that can affect its members.

According to Hess et al., (2012), "supervision is making sure the activities are effectively implemented by those responsible for doing so."This definition implies that supervision is an activity carried out by a supervisor with full responsibility. Here supervisors are usually those who focus on the day-to-day operations of the department and evaluate those who do.

The definition of supervision according to Rue and Byars (2010) is supervision is the first level of management in an organization concerned with encouraging the members of a work unit to contribute positively toward accomplishing the organization's goals and objectives.

Terry (2005: 178) defines supervision as follows; supervision is an activity to monitor whether the organization's movements are by the plan or not. Moreover, supervise the use of resources in the organization that will be used effectively and efficiently without deviating from the plan. This definition implies that supervision is an activity carried out by a leader in order to optimize the existing resources within the organization in order to achieve the expected goals.

Supervision according to the Peretomode cited by Oleforo et al. (2015), "supervision is that phase of school management which focuses primarily on the achievement of the appropriate expectation of educational systems. It is an indispensable function of the school managers". It means that means supervision is an activity or exercise in which a professional or a group of professional supervisors helps in facilitating learning by improving the learning and teaching environment in schools through guidance, advice, and encouragement for both students and teachers.

Some of the principal's activities as a supervisor as explained by Rue and Byars (2010): A leader in carrying out tasks in an organization by carrying out activities including; (1) planning, including determining the most effective way to achieve the work that must be done by the working group and the most effective way to achieve goals. (2) Organizing, distribute work between employees in the workgroup and arrange work so that it flows smoothly. (3) Staffing, relating to getting and developing the best people. (4) Leading, direct and involve employee behavior towards the achievement of work performance and provide a workplace where people can be motivated to achieve work goals. (5) Controlling, determining how well the work being doneis compared to what was planned. 
Improvement of Teachers' Performance through Development of Emotional Intelligence, Organizational Culture and Principal's Supervision

\section{RESEARCH METHODS}

This study was conducted at the public elementary schools in Jambi City totaling 197 schools. The study took place from October 2016 to October 2018. The method of this study used a combination research method (Mixed Methods). The population in this study was all public elementary school teachers in Jambi City with 948 people. As for this study, the sampling method with the technique of Multi-Stage Random Sampling was employedto obtain the number of 282 teachers.The research hypothesis was tested using multiple regressions. Before hypothesis testingdata wastested for normality and homogeneity (Moleong, 2003).

\section{Results}

The results of data analysis for normality and homogeneity are listed in Table 1 and Table 2.

Table1: Summary of Test for Normality

\begin{tabular}{|l|l|l|l|l|}
\hline No. & \multicolumn{1}{|c|}{ Estimation } & \multicolumn{1}{c|}{$\mathbf{L}_{\text {count }}\left(\mathbf{L}_{\mathbf{0}}\right)$} & \multicolumn{1}{c|}{$\mathbf{L}_{\text {table }}$} & \multicolumn{1}{c|}{ Decision } \\
\hline 1 & $\mathrm{X}_{1}-\mathrm{Y}$ & 0.0498 & 0.0528 & Normal \\
\hline 2 & $\mathrm{X}_{2}-\mathrm{Y}$ & 0.0484 & 0.0528 & Normal \\
\hline 3 & $\mathrm{X}_{3}-\mathrm{Y}$ & 0.0477 & 0.0528 & Normal \\
\hline \multicolumn{4}{|l}{} \\
\hline
\end{tabular}

Table2: Summary of Test Homogeneity

\begin{tabular}{|l|l|l|l|}
\hline \multirow{2}{*}{ Grouping } & \multicolumn{2}{|c|}{ Test $\mathbf{F}$} & \multirow{2}{*}{ Conclusion } \\
\cline { 2 - 3 } & $\mathrm{F}_{\text {count }}$ & $\mathrm{F}_{\text {table }}$ & \\
\hline $\mathrm{Y}$ top $\mathrm{X}_{1}$ & 1.06 & 1.22 & Homogeneous \\
\hline $\mathrm{Y}$ on $\mathrm{X}_{2}$ & 1.16 & 1.22 & Homogeneous \\
\hline $\mathrm{Y}$ top $\mathrm{X}_{3}$ & 1.07 & 1.22 & Homogeneous \\
\hline Requirement:: $\mathrm{F}_{\text {count }}<\mathrm{F}_{\text {table }}$ \\
\hline
\end{tabular}

Hypothesis testing is done by correlation and regression analysis. Testing of the first, second and third hypotheses uses simple analysis and regression, while the fourth hypothesis uses multiple correlation analysis. Hypothesis test results show the following results:

Table3: Summary of Regression Equations

\begin{tabular}{|l|l|l|l|l|l|}
\hline Model & \multicolumn{1}{|c|}{ Regression Equation } & \multicolumn{3}{c|}{ Significance } & \multirow{2}{*}{ Conclusion } \\
\hline & & $\mathrm{F}_{\text {count }}$ & $\mathrm{F}_{\text {tabel }(\alpha=0.05)}$ & $\mathrm{F}_{\text {tabel }(\alpha=0.01)}$ & \\
\hline $\mathrm{Y}-\mathrm{X}_{1}$ & $\hat{\mathrm{Y}}=68.448+0.566 \mathrm{X}_{1}$ & 173.037 & 3.875 & 6.726 & Very significant \\
\hline $\mathrm{Y}-\mathrm{X}_{2}$ & $\hat{\mathrm{Y}}=75.242+0.544 \mathrm{X}_{2}$ & 165.158 & 3.875 & 6.726 & Very significant \\
\hline $\mathrm{Y}-\mathrm{X}_{3}$ & $\hat{\mathrm{Y}}=58.260+0.637 \mathrm{X}_{3}$ & 270.372 & 3.875 & 6.726 & Very significant \\
\hline $\mathrm{Y}-$ & $\hat{\mathrm{Y}}=42.540+0.242 \mathrm{X}_{1}+0.164 \mathrm{X}_{2}+0.338 \mathrm{X}_{3}$ & 106.045 & 2.637 & 3.852 & Very significant \\
$\mathrm{X}_{1} \mathrm{X}_{2} \mathrm{X}_{3}$ & & & & & \\
\hline
\end{tabular}

Table4: Summary of Significance Correlation

\begin{tabular}{|c|c|c|c|c|c|}
\hline \multirow[t]{2}{*}{ No. } & \multirow{2}{*}{$\begin{array}{l}\text { Correlation } \\
\text { Coeficient }\end{array}$} & \multicolumn{3}{|c|}{ Significance } & \multirow[t]{2}{*}{ Conclusion } \\
\hline & & $\mathrm{F}_{\text {count }}$ & $\mathrm{F}_{\text {tabel }(\alpha=0.05)}$ & $\mathrm{F}_{\text {tabel }(\alpha=0.01)}$ & \\
\hline 1. & $\mathrm{r}_{\mathrm{y} 1}=0.618$ & 173.037 & 3.875 & 6.726 & $\begin{array}{l}\text { Emotional intelligence }\left(\mathrm{X}_{1}\right) \text { positively } \\
\text { affects teachers' performance }(\mathrm{Y})\end{array}$ \\
\hline 2. & $r_{\mathrm{y} 2}=0.609$ & 165.158 & 3.875 & 6.726 & $\begin{array}{l}\text { Organizational culture }\left(\mathrm{X}_{2}\right) \text { positively } \\
\text { affects teachers' performance }(\mathrm{Y})\end{array}$ \\
\hline 3. & $r_{y 3}=0.701$ & 270.372 & 3.875 & 6.726 & $\begin{array}{l}\text { Principals' supervision }\left(\mathrm{X}_{3}\right) \text { positively } \\
\text { affects teachers' performance }(\mathrm{Y})\end{array}$ \\
\hline 4. & $\mathrm{r}_{\mathrm{y} 123}=0.706$ & 106.045 & 2.637 & 3.852 & $\begin{array}{l}\text { Emotional intelligence }\left(\mathrm{X}_{1}\right) \text {, } \\
\text { Organizational culture }\left(\mathrm{X}_{2}\right) \text {, Principals' } \\
\text { supervision }\left(\mathrm{X}_{3}\right) \text { simultaneously affect } \\
\text { teachers' performance }(\mathrm{Y})\end{array}$ \\
\hline
\end{tabular}

\section{DISCUSSION}

Based on the scientific identification theory or operation research in education management (SITOREM) or scientific introduction theory for operations research in the field of education management, the reduction in suggestions or recommendations from the results of this study 
will use the SITOREM method. This is a scientific identification theory that is a theory that explains the steps in system analysis, modeling, and simulation ( Hardhienata, 2017). Primary considerations for the preparation of problem handling include three criteria, namely: 1) the strength of the relationship between the independent variables studied with the dependent variable. 2) the order of indicators that have been prioritized, and 3) indicator values from the results of field research after considering these three criteria, the sequence is made to determine the priority of actions to improve the state of the dependent variable.

From the results of multiple regression of this quantitative study, it can be seen between the three independent variables; itis known that the value of the relationship between independent variables and the dependent variable can be seen from the coefficient of determination. The coefficient of determination of emotional intelligence variables with a performance of $\mathrm{r}_{\mathrm{y} 1}{ }^{2}=$ $38.20 \%$, organizational culture variables with teacher performance of $\mathrm{r}_{\mathrm{y} 2}{ }^{2}=37.10 \%$, variable supervision of principals with teacher performance of $\mathrm{r}_{\mathrm{y} 3}{ }^{2}=49.10 \%$.


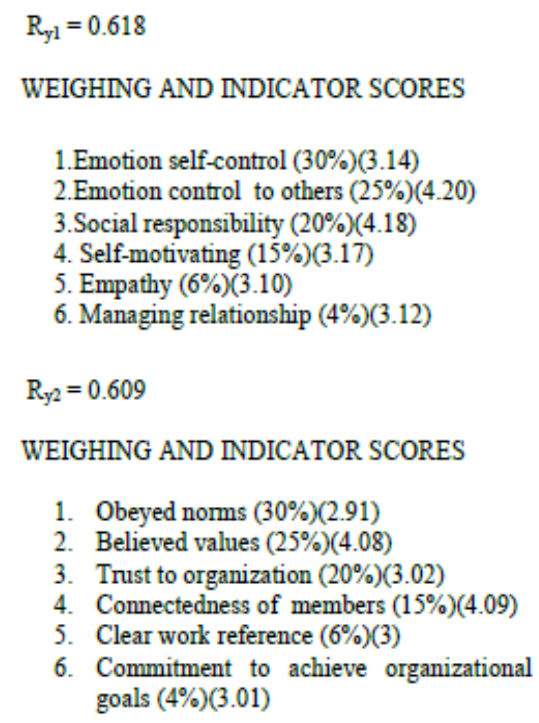

\section{WEIGHING AND INDICATOR SCORES}

1. Obeyed norms $(30 \%)(2.91)$

2. Believed values $(25 \%)(4.08)$

3. Trust to organization $(20 \%)(3.02)$

4. Connectedness of members $(15 \%)(4.09)$

5. Clear work reference $(6 \%)(3)$

6. Commitment to achieve organizational goals $(4 \%)(3.01)$

$R_{y 3}=0.701$

\section{WEIGHING AND INDICATOR SCORES}

1. Developing teachers' knowledge $(30 \%)(3.03)$

2. Developing teaching competency $(25 \%)(3.12)$

3. Problem solving among teachers $(20 \%)(3.13)$

4. Career development guidance $(15 \%)(4.20)$

5. Managing relationship teachers to community $(6 \%)(4.19)$

6. Guiding curriculum development $(4 \%)(3.01)$

\section{WEIGHING AND INDICATOR SCORES}

1.Result of work assigned ( $30 \%)(3.26)$

2. Quality of work $(25 \%)(3.22)$

3. Initiatives $(20 \%)(3.33)$

4. Cooperation with others $(15 \%)(3.21)$

5. Punctuality $(10 \%)(3.22)$

Figure1: SITOREM Analysis

When viewed from the influence of each independent variable on the dependent variable (teacher performance), the principal supervising variable gives the most considerable influence where the correlation coefficient is 0.701 , which means the coefficient of determination (influence) is $49.10 \%$, followed by the emotional intelligence variable with the coefficient the correlation is 0.618 , this means that the determination coefficient is $38.20 \%$ and the organizational culture variable with its 
correlation coefficient is 0.609 , which means that the determination coefficient is $37.10 \%$.

From the results of the priority sequence and calculation of each variable obtained from research in the field, then a sequence to determine the priority of actions to improve is listed as follows.

- Developing teachers' knowledge

- Developing teaching competency

- Problem-solving among teachers

- Guiding curriculum development

- Emotion self-control

- Self-motivating

- Empathy

- Managing relationship

- Obeyed norms

- Trust to organization

- Clear work reference

- Commitment to achieve organizational goals

- Result of work assigned

- Quality of work

- Initiatives

- Cooperation with others

- Punctuality

Further, the analysis also generates an area that should be maintained as follows:

- Emotion control to others

- Social responsibility

- Believed values

- Connectedness among members

- Career development guidance

- Managing relationship teachers to community

\section{CONCLUSION}

Based on the results of the analysis of research data, both quantitatively and qualitatively reinforced, it can be concluded that this study has found efforts to improve teacher performance by identifying and developing variables emotional intelligence, organizational culture and supervision of the principal are as follows:

1. The strength of the relationship between emotional intelligence and teacher performance is strong $\left(\mathrm{r}_{\mathrm{y} 1}=0.618, \mathrm{p}<0.01\right)$ means that the higher the development of emotional intelligence is predicted to improve teacher performance.

2. The strength of the relationship between organizational culture and teacher performance is relatively strong $\left(\mathrm{r}_{\mathrm{y} 2}=0.609, \mathrm{p}<0.01\right)$ means that the higher the organizational culture is predicted to improve teacher performance. 
3. The strength of the relationship between school principal supervision and teacher performance is relatively strong $\left(r_{\mathrm{y} 3}=0.701, \mathrm{p}<0.01\right)$ means that the higher the supervision of the principal is predicted to be able to improve teacher performance.

4. The strength of the relationship between emotional intelligence $\left(X_{1}\right)$, organizational culture $\left(X_{2}\right)$ and supervision of the principal $\left(\mathrm{X}_{3}\right)$ together with teacher performance $(\mathrm{Y})$ is classified as strong $\left(r_{y 123}=0.706, p<0.01\right)$ means more high development of emotional intelligence, coupled with the strengthening of organizational culture and the effectiveness of supervising principals together, it is predicted to improve teacher performance.

\section{REFERENCES}

[1] Colquitt, Jasson A. Jeffery A. Lepine, Michael J. Wesson. (2009). Organizational Behavior. New York: McGraw Hill International Edition.

[2] DuBrin, Andrew J. (2012). Essentials of Management, Ninth Edition. Mason: South-Western, Cengage Learning.

[3] Hardhienata, S. The development of scientific identification theory to conduct operation research in education management, IOP Conf. Series: Materials Science and Engineering 166 (2017) 012007 doi: 10.1088 / 1757 - 899X / 166 / I / 012007.

[4] Hess, Kären Matison dan Christine Hess Orthmann. (2012). Management and Supervision in Law Enforcement, Sixth Edition. New York: Delmar, Cengage Learning.

[5] Luthans, Fred. (2011). Organizational Behavior, twelfth edition. New York: McGraw-Hill.

[6] Mohtar, N. S., \& Rajiani, I. (2016). Conceptual Model in Using Ability and Opportunity as GHRM. International Business Management, 10(17), 3840-3846.

[7] Moleong, Lexy J. (2003). Metodologi Penelitian Kualitatif. Bandung: Pustaka Jaya.

[8] Oleforo, Ngozika A. Usen I. Ikpe, Emmanuel A. Bassey. (2015). "Management Strategies and Secondary School Teachers' Job Performance in Akwa Ibom South Senatorial District" Asian Journal of Management Sciences \& Education Vol. 4 (2) April.

[9] Petrides, K. V. \& A. Furnham. (2010). "The Role of Trait Emotional Intelligence in A Gender-Specific Model of Organizational Variables" Journal of Applied Social Psychology.

[10] Rue, Leslie W.,and Lioyd L. Byars. (2010). Supervision, Key Link to Productivity, tenth edition. New York: McGraw-Hill Irwin.

[11] Sedarmayanti. (2009). Sumber Daya Manusia dan Produktivitas Kerja. Bandung: CV Mandar Maju.

[12] Zeidner, Moshe Gerald Matthews, and Richard D.Roberts. (2009). "What We Know About Emotional Intelligence: How It A Acts Learning, Work, Relationships, And Our Mental Health" Massachusetts: Massachusetts Institute of Technology.

Citation: Mualimah, Soewarto Hardhienata, Entang. “Improvement of Teachers' Performance through Development of Emotional Intelligence, Organizational Culture and Principal's Supervision" International Journal of Managerial Studies and Research (IJMSR), vol 7, no. 4, 2019, pp. 29-34. doi: http://dx.doi.org/10. 20431/2349-0349.0704004.

Copyright: () 2019 Authors. This is an open-access article distributed under the terms of the Creative Commons Attribution License, which permits unrestricted use, distribution, and reproduction in any medium, provided the original author and source are credited. 